\title{
Analisis Yuridis terhadap Peranan Bank Syariah dalam Kegiatan Perbankan di Indonesia
}

\author{
Wulanmas A.P.G. Frederik \\ Fakultas Hukum Universitas Sam Ratulangi \\ Jl. Kampus Unsrat Bahu Manado 95115 \\ wulanmas_racyfrederik@yahoo.com
}

\begin{abstract}
The presence of Sharia banks offers customers with various banking products. It is just different from conventional banks in terms of pricing, both the selling price and the buying price. As for the types of products offered by Sharia banks are: Al-wadi'ah (savings), Financing with profit sharing, Bai'alMurabahah, Bai'as-salam, Bai'Al-istihna, Al-ljarah (Leasing), Al-Wakalah (Mandate), Al-Kafalah (warranty), Al-Hawalah, Ar-Rahn. The aim of this paper is: to find out the position of Sharia Banks in the Indonesian banking system, and to determine the role of Sharia Banks in the provision of banking services. The research method in this research is normative juridical approach. Based on the results and discussion of Sharia Bank position in the Indonesian banking system, the targets of Sharia banking development are: enhancing the benefits of Sharia banking for the public welfare; realizing a healthy, competitive, and efficient Sharia banking; assuring the compliance of Sharia principles consistently based on mudaraba (partnership); and assuring the precautionary principles. Furthermore, the role of Sharia Banks in the provision of banking services, which is based The Bank of Indonesia Regulation 6/ 17/PBI/2004 on Rural Banks based on Sharia principles and The Bank of Indonesia Regulation 6/24/ PBI/2004 on Commercial Banks Conducting Business Based on Sharia Principles: Sharia Monitoring and Reporting Procedures for Monitoring Results to Sharia Supervisory Board.
\end{abstract}

Key words : Systems, existence, management, sharia banks

\begin{abstract}
Abstrak
Keberadaan bank Syariah menawarkan berbagai pilihan produk perbankan bagi nasabah. Perbedaannya dengan bank konvensional hanya terletak pada harga, baik harga jual maupun harga beli. Sedangkan untuk jenis-jenis produk yang ditawarkan, bank Syariah memiliki: Al-wadi'ah (tabungan), pembiayaan dengan bagi hasil, Bai'al-Murabahah, Bai'as-salam, Bai'al-istihna, Al-ljarah (Sewa Guna Usaha), Al-Wakalah (Perwakilan), Al-Kafalah (Jaminan), Al-Hawalah, dan Ar-Rahn. Penelitian ini bertujuan untuk mempelajari kedudukan bank-bank Syariah dalam sistem perbankan Indonesia dan mengetahui peran bank-bank Syariah dalam penyediaan jasa perbankan. Metode penelitian yang digunakan adalah pendekatan yuridis normatif. Berdasarkan hasil pembahasan tentang kedudukan bank Syariah dalam sistem perbankan Indonesia, tujuan-tujuan pengembangan perbankan Syariah adalah untuk: meningkatkan keuntungan perbankan Syariah untuk kesejahteraan rakyat, mewujudkan perbankan Syariah yang sehat, berdaya saing, dan efisien, memastikan kepatuhan terhadap prinsipprinsip Syariah secara berkesinambungan berdasarkan mudaraba (kemitraan), dan menjamin prinsipprinsip pencegahan dini. Lebih lanjut, peran bank-bank Syariah dalam penyediaan layanan perbankan diatur dalam Peraturan Bank Indonesia No.6/17/PBI/2004 tentang Bank-bank Pedesaan yang Berprinsip Syariah dan Peraturan Bank Indonesia No.6/24/PBI/2004 tentang Bank-bank Komersial yang Menjalankan Bisnis Berdasarkan Prinsip Syariah: Pengawasan Syariah dan Tata Laksana Pelaporan Hasil Pengawasan kepada Badan Pengawas Syariah.
\end{abstract}

Kata kunci : Sistem, keberadaan, manajemen, bank-bank syariah 


\section{Pendahuluan}

Bank menurut Undang-Undang Nomor 7 Tahun 1992 tentang Perbankan sebagaimana yang telah diubah dengan Undang-Undang Nomor 10 Tahun 1998 adalah Badan usaha yang menghimpun dana dari masyarakat dalam bentuk simpanan dan menyalurkannya kepada masyarakat dalam bentuk kredit dan atau bentuk-bentuk lainnya dalam rangka meningkatkan taraf hidup rakyat banyak. ${ }^{1} \mathrm{Hal}$ ini berarti bahwa bank merupakan perusahaan yang bergerak dalam bidang keuangan artinya aktivitas perbankan selalu berkaitan dalam bidang keuangan.

Sebagai gambaran umum, berikut ini dikutip beberapa pendapat tentang pengertian bank. ${ }^{2}$ Pertama, Perbankan pada umumnya ialah kegiatan-kegiatan dalam menjual/belikan mata uang, surat efek dan instrumen-instrumen yang dapat diperdagangkan. Penerimaan deposito untuk memudahkan penyimpanannya atau untuk mendapatkan bunga, dan atau pembuatan, pemberian pinjaman-pinjaman dengan atau tanpa barang-barang tanggungan, penggunaan uang yang ditempatkan atau diserahkan untuk disimpan; Kedua, Bank merupakan salah satu badan usaha lembaga keuangan yang bertujuan memberikan kredit dan jasa-jasa. Adapun pemberian kredit itu dilakukan baik dengan modal sendiri atau dengan dana-dana yang dipercayakan oleh pihak ketiga maupun dengan jalan memperedarkan alatalat pembayaran baru berupa uang giral.

Membangun industri perbankan yang kuat dan sehat adalah suatu prasyarat mutlak dalam perekonomian nasional, sebab melalui peran intermediasi perbankan itulah roda perekonomian bisa digerakkan lebih cepat, sehingga stabilitas ekonomi juga dapat terpelihara. Jadi, tidak mengherankan apabila tuntutan yang dibebankan kepada perbankan untuk menjalankan kegiatan usahanya dengan mengedepankan prinsip prudensialitas, termasuk diperlukannya arah yang jelas dalam upaya menciptakan industri perbankan yang sehat, kuat, dan efisien.

Prinsip utama yang digunakan dalam melakukan pengawasan bank pada awalnya, adalah: ${ }^{3}$ asas perbankan yang sehat; dan asas perkreditan yang sehat. Kehadiran bank yang berdasarkan syari'ah di Indonesia masih relatif baru, yaitu baru pada awal 1990-an, meskipun masyarakat Indonesia merupakan masyarakat muslim terbesar di dunia. Prakarsa untuk mendirikan Bank Syari'ah di Indonesia

\footnotetext{
${ }^{1}$ Sentosa Sembiring, Hukum Perbankan, Mandar Maju, Bandung, 2000, hlm. 84.

${ }^{2}$ Abdurrahman, A., Ensikopedia Ekonomi Kenangan Perdagangan, Pradnya Paramita, Jakarta, 1993, hlm. 80.

${ }^{3}$ Permadi Gandapradja, Dasar dan Prinsip Pengawasan Bank, PT Gramedia Pustaka Utama, Jakarta, 2005, hlm. 25
} 
dilakukan oleh Majelis Ulama Indonesia (MUI) pada 18-20 Agustus 1990. Namun diskusi tentang bank syariah sebagai basis ekonomi Islam sudah mulai dilakukan pada awal 1980.

Bank syariah juga menawarkan nasabah dengan beragam produk perbankan. Hanya saja bedanya dengan bank konvensional adalah dalam hal penentuan harga, baik terhadap harga jual maupun harga belinya. Produk-produk yang ditawarkan sudah tentu sangat islami, termasuk dalam memberikan pelayanan kepada nasabahnya.

Adapun jenis-jenis produk bank Syariah yang ditawarkan adalah: Al-wadi'ah (simpanan), Pembiayaan dengan bagi hasil, Bai'al-Murabahah, Bai'as-salam, Bai' Al-istihna, Al-Ijarah (Leasing), Al-Wakalah (Amanat), Al-Kafalah (Garansi), Al-Hawalah, Ar-Rahn.

\section{Rumusan Masalah}

Sehubungan dengan latar belakang tersebut di atas, maka yang menjadi rumusan masalah, adalah: 1. Bagaimana kedudukan Bank Syariah di dalam sistem perbankan Indonesia? 2. Bagaimana peranan Bank Syariah di dalam penyediaan jasa-jasa perbankan?

\section{Tujuan Penelitian}

Tujuan dalam penelitian ini, adalah sebagai berikut: 1. Untuk mengetahui kedudukan Bank Syariah di dalam sistem perbankan Indonesia; 2. Untuk mengetahui peranan Bank Syariah di dalam penyediaan jasa-jasa perbankan.

\section{Metode Penelitian}

Penelitian ini adalah penelitian yuridis nomatif. Pendekatan yuridis yaitu penelitian hukum normatif/doktrinal yang bersifat preskriptif. ${ }^{4}$ Pengumpulan bahan dilakukan dengan berbagai teknik dan cara seperti mengumpulkan data sekunder yang terdiri dari: a. bahan hukum primer, yaitu bahan hukum yang mengikat berupa peraturan perundang-undangan yang berhubungan dengan perundang-undangan

\footnotetext{
${ }^{4}$ Ilmu hukum bersifat preskriptif mempelajari tujuan hukum, nilai-nilai keadilan, validitas aturan hukum, konsep-konsep hukum dan norma-norma hukum. Peter Mahmud Marzuki, Penelitian Hukum, Preneda Media, Jakarta, 2005. hlm. 22.
} 
perbankan yang ada kaitannya dengan Bank Syariah ini. b. bahan hukum sekunder, yaitu bahan yang memberikan penjelasan terhadap bahan hukum primer, seperti kepustakaan hukum, jurnal hukum serta karya tulis yang berkaitan dengan penelitian ini. c. bahan hukum tertier, yaitu bahan-bahan lainnya yang bersifat untuk lebih menjelaskan bahan hukum primer dan sekunder seperti kamus hukum, kamus ekonomi, dan ensiklopedi. Bahan hukum dikumpulkan dari berbagai pustaka, baik berasal dari dalam maupun luar negeri. Tahap selanjutnya bahan hukum disusun secara sistematis komprehensif berdasarkan urutan dari bahan hukum. Data yang telah dikumpulkan dengan studi kepustakaan tersebut selanjutnya dianalisis dengan mempergunakan metode analisis kualitatif yang didukung oleh logika berpikir secara deduktif, kemudian dilakukan pemeriksaan terhadap data yang terkumpul melalui wawancara secara langsung dan terarah. Analisis untuk data kualitatif dilakukan dengan cara pemilihan terhadap pasal-pasal yang berisi kaidahkaidah hukum perbankan sehingga dari analisis data ini dapat ditemukan suatu jawaban terhadap permasalahan yang terjadi dalam sistem perbankan Syariah.

\section{Hasil Penelitian dan Pembahasan}

\section{Kedudukan Bank Syariah di dalam Sistem Perbankan Indonesia}

\section{Sejarah Singkat Bank Syari'ah}

Perkembangan sejarah kegiatan Bank Syari'ah di berbagai negara mengalami beberapa tahap, yaitu: 1. 1940-an pertama kali dilakukan adalah di Pakistan dan Malaysia pada sekitar, 2. 1963 di Mesir pada berdiri Islamic Rural Bank. Bank ini beroperasi di pedesaan Mesir dan masih berskala kecil. 3. 1975 berdiri Dubai Islamic Bank di Uni Emirat Arab. 4. 1977 di Kuwait berdiri Kuwait Finance House yang beroperasi tanpa bunga. 5. selanjutnya kembali di Mesir pada 1978 berdiri Bank Syari'ah yang diberi nama Faisal Islamic Bank. Langkah ini kemudian diikuti oleh Islamic International Bank for Invesment and Development. 6. Di Siprus 1983 berdiri Faisal Islamic Bank of Kibris. 7. pada 1983 di Malaysia Bank Syari'ah mulai berlaku secara nasional sejak dikeluarkannya Undang-Undang Perbankan Islam. 8. kemudian di Turki negara yang berideologi sekuler Bank Syari'ah lahir 1984 yaitu dengan hadirnya Daar al-Maal al-Islami Sentra Faisal Finance Institution dan mulai beroperasi 1985. 9. Pada 1985 Pemerintah Pakistan mengkonversi seluruh sistem 
perbankan di negaranya menjadi sistem perbankan syari'ah. Salah satu negara pelopor utama dalam melaksanakan sistem perbankan syari'ah secara nasional adalah Pakistan. Sebelumnya pada 1979 beberapa institusi keuangan terbesar di Pakistan telah menghapus sistem bunga dan mulai tahun itu juga pemerintah Pakistan mensosialisasi pinjaman tanpa bunga, terutama kepada petani dan nelayan. 10 . kehadiran bank yang berdasarkan syari'ah di Indonesia pada awal 1990-an dan masih relatif baru, yaitu baru, meskipun masyarakat Indonesia merupakan masyarakat muslim terbesar di dunia. Prakarsa untuk mendirikan Bank Syari'ah di Indonesia dilakukan oleh Majelis Ulama Indonesia (MUI) pada 18-20 Agustus 1990. Namun diskusi tentang bank syariah sebagai basis ekonomi Islam sudah mulai dilakukan pada awal 1980. Bank Syariah pertama di Indonesia merupakan hasil kerja tim perbankan MUI yaitu dengan dibentuknya PT. Bank Muamalat Indonesia (BMI) yang akte pendiriannya ditandatangani 1 November 1991. Bank ini ternyata berkembang cukup pesat sehingga saat ini BMI sudah memiliki puluhan cabang yang tersebar di beberapa kota besar seperti Jakarta, Surabaya, Bandung, Makassar dan kota lainnya. Dalam perkembangan selanjutnya kehadiran bank syariah di Indonesia khususnya cukup menggembirakan. Di samping BMI, saat ini juga telah lahir Bank Syariah milik Pemerintah seperti Bank Syariah Mandiri (BSM). Kemudian berikutnya berdiri Bank Syariah sebagai cabang dari bank konvensional yang sudah ada, seperti Bank BNI, Bank IFI dan BPD Jabar. Bank - bank Syariah lain yang direncanakan akan membuka cabang adalah BRI, Bank Niaga dan Bank Bukopin.

Kehadiran Bank Islam membawa pengaruh pada perkembangan bank-bank, sehingga sudah tersebar di berbagai negara - negara muslim dan non muslim, yaitu: di Benua Amerika, Australia dan Eropa. Bahkan banyak perusahaan keuangan dunia seperti ANZ, Chase Chemical Bank dan Citibank telah membuka cabang yang berdasarkan syariah.

\section{Perbankan Konvensional dan Perbankan Syariah}

Jenis bank tersebut perlu kiranya di bahas dalam rangka memahami secara keseluruhan mengenai perbankan yang ada di Indonesia.

\section{Perbankan Konvensional}

Perbankan konvesional telah melewati sejarah yang sangat panjang, paling tidak dimulai sejak kira-kira 2.000 Sebelum Masehi di Babylonia, yaitu berupa lembaga keuangan semacam bank. Lembaga semacam bank ini meminjamkan emas dan perak 
dengan tingkat bunga 20\% setiap bulan, lembaga tersebut di kenal dengan sebutan Tamples of Babylon. Sesudah zaman Babylon, pada 500 SM menyusul Yunani di dirikan semacam bank, yaitu yang di kenal dengan Greek Tample, yang kegiatannya menerima simpanan dengan memungut biaya penyimpanannya serta meminjamkannya kembali ke masyarakat. ${ }^{5}$ Di Indonesia perbankan konvensional diperkenalkan oleh Belanda melalui Vereenigde Oostindische Compagnie (VOC) yang melakukan ekspansi ke nusantara. VOC di jawa pada 1974 mendirikan De Bank van Leening, yang kemudian menjadi De Bank Courant en bank van Leening, pada 1752. Bank itu adalah bank pertama yang lahir di nusantara, cikal bakal dari dunia perbankan Indonesia selanjutnya. ${ }^{6}$

Konsep perbankan konvensional berdasarkan bunga sebagai instrumennya sehingga dikenal time value of money sebagai paradigma yang menghasilkan metode present value dan future value. Perbankan selanjutnya di atas transaksi uang di bank konvensional, diantaranya, yaitu berupa pertukaran mata uang dengan kurs yang tidak tetap, ditambah instrumen bunga sehingga melahirkan transaksi bersifat spekulasi (al - gharar) dan tanpa didasarkan pada kegiatan usaha riil, seperti swap.

Menurut Muhammad Syarif Surbakti, dalam pembahasan perbedaan antara perbankan syariah dan perbankan konvensional, yaitu: ${ }^{7}$ a. Bank konvensional, karakteristik hubungan adalah kreditur-debitur, kedua belah pihak telah menetapkan besarnya pendapatan dan biaya yang menjadi hak dan beban adalah kreditur - debitur, kedua belah pihak telah menetapkan besarnya pendapatan dan biaya yang menjadi hak dan beban masing-masing dalam bentuk riba; b .Umumnya kriteria usaha berorientasi pada tingkat keuntungan, kelayakan arus kas, dan pengamanan kredit, namun ada pembatasan secara kualitatif hanya berdasarkan nilai etika yang dapat berubah sesuai perubahan nilai masyarakatnya. Secara etimologis istilah kredit berasal dari bahasa Latin, credere $^{8}$ yang berarti kepercayaan. Hal ini menunjukkan bahwa yang menjadi dasar pemberian kredit oleh bank kepada nasabah debitur adalah kepercayaan. Apabila dihubungkan dengan bank, maka terkandung pengertian bahwa bank selaku kreditur percaya meminjamkan sejumlah uang kepada nasabah/debitur, karena debitur dapat dipercaya kemampuannya

\footnotetext{
${ }^{5}$ Djumhana Muhamad, Hukum Perbankan di Indonesia, PT Citra Aditya Bakti, Bandune, 1996, hlm. 38

${ }^{6}$ http://www.bi.go.id

${ }^{7}$ Muhammad Syarif Surbakti, Pengaturan Khusus Bagi Perbankan Syariah, http://www.tazkiaonline.com/ artikel,php3?sid $=517$

${ }^{8}$ Hala Savelberg, De crediet hypotheek, Leiden, 1885, hlm. 33
} 
untuk membayar lunas pinjamannya setelah jangka waktu yang ditentukan. ${ }^{9}$ Tenggang waktu antara pemberian dan penerimaan kembali prestasi ini menurut Mgs. Edy Putra Tje Aman, merupakan suatu hal yang abstrak, yang sukar diraba, karena masa antara pemberian dan penerimaan prestasi tersebut dapat berjalan dalam beberapa bulan, tetapi dapat pula berjalan beberapa tahun ${ }^{10}$; c. Ruang lingkup bidang usaha bank konvensional terbatas pada mekanisme pinjam - meminjam dengan instrumen ribawi; $d$. Akuntansi dan penyajian laporan keuangan berorientasi pada kepentingan para pemegang saham dan tidak di kenal konsep pertanggungjawaban sosial dan keadilan, tetapi dalam satu dekade terakhir, ada kecenderungan akuntansi konvensional mengarah pada konsep yang sejalan dengan Islam, seperti berkembangnya konsep akuntansi pertanggungjawaban, akuntansi sosial, akuntansi SDM, dan sebagainya. e. Bagi bank konvensional, konsep corporate governance terbatas pada pertanggung jawaban kepada pemilik perusahaan dan berlandaskan nilainilai etika.

\section{Perbankan Syariah}

Perbankan syariah memiliki dinamika, mekanisme, dan perkembangan sendiri. Di Indonesia, kajian tentang perbankan syariah sudah muncul sejak 1980-an. Namun, realisasinya baru pada 1991 dengan munculnya bank syariah pertama di Indonesia, yaitu Bank Muamalat Indonesia (BMI) yang mulai beroperasi pada 1992.

\section{PERKEMBANGAN REGULASI BANK SYARIAH}

\begin{tabular}{|l|l|l|}
\hline TAHUN & \multicolumn{1}{|c|}{ PERISTIWA } & \multicolumn{1}{c|}{ SUBSTANSI MATERI } \\
\hline 1990 & Lokasi MUI & Kesepakatan untuk membentuk bank syariah \\
1992 & $\begin{array}{l}\text { Pengenalan dual banking } \\
\text { system }\end{array}$ & $\begin{array}{l}\text { Undang-Undang Nomor 7 Tahun 1992 tentang Perbankan } \\
\text { yang memberikan kesempatan operasi bagi hasil }\end{array}$ \\
& Pengenalan dual banking & $\begin{array}{l}\text { - Undang-Undang Nomor 10 Tahun 1998 tentang Perubahan } \\
\text { system }\end{array}$ \\
& & atas Undang - Undang Nomor 7 Tahun 1992 tentang \\
& Perbankan, bank Indonesia mengakui keberadaan bank \\
& syariah dan bank konvensional di perkenankan membuka \\
& kantor cabang syariah. \\
& & - Dual system dalam pengelolaan bank yakni secara \\
& konversional dengan menggunakan bunga (interest) untuk \\
& & setiap peminjaman atau penyimpanan dana, serta \\
& menggunakan sistem bagi hasil yang merupakan dasar \\
& perbankan syariah. \\
& &
\end{tabular}

${ }^{9}$ Sidharta P Soerjadi, Segi-segi Hukum Perkreditan di Indonesia, Kertas Kerja dalam Simposium Aspek-aspek Hukum Masalah Perkreditan, BPHN Binacipta, 1987, hlm. 11

${ }^{10}$ Mgs Edy Putra Kredit Perbankan Suatu Tinjanan Yuridis, Liberty, Yogyakarta, 1989, hlm. 10. 


\begin{tabular}{|c|c|c|}
\hline TAHUN & PERISTIWA & SUBSTANSI MATERI \\
\hline 1999 & $\begin{array}{l}\text { Pengenalan instrumen } \\
\text { moneter syariah }\end{array}$ & $\begin{array}{l}\text { Undang - Undang Nomor } 23 \text { Tahun } 1999 \text { tentang Bank } \\
\text { Indonesia, memberikan tanggung jawab dan kewenangan } \\
\text { kepada Bank Indonesia untuk melakukan pengaturan dan } \\
\text { pengawasan perbankan, termasuk bank syariah serta Bank } \\
\text { Indonesia berwenang untuk menetapkan kebijakan moneter } \\
\text { berdasarkan prinsip syariah. }\end{array}$ \\
\hline 2000 & $\begin{array}{l}\text { Pengenalan pasar uang } \\
\text { syariah }\end{array}$ & $\begin{array}{l}\text { Pengenalan instrumen pasar uang syariah, di antaranya, } \\
\text { Sertifikat Wadiah Bank Indonesia yang di atur dalam } \\
\text { Peraturan Bank Indonesia Nomor } 2 / 9 / \mathrm{PBI} / 2000\end{array}$ \\
\hline 2002 & $\begin{array}{l}\text { P e } n \text { y e } m p \text { u } n \text { a a } n \\
\text { jaringan kantor }\end{array}$ & $\begin{array}{l}\text { Pengaturan Bank Indonesia Nomor 4/1/PBI/2002, Mengatur } \\
\text { Mengenai Konversi BUK menjadi BUS; Konversi KCK menjadi } \\
\text { BUS; Konversi KCK menjadi Kantor Cabang Syariah; Konversi } \\
\text { KCP/KK menjadi Kantor Cabang Syariah; pembukaan KCPS } \\
\text { di KCK dan unit syariah (US) di KCK }\end{array}$ \\
\hline 2003 & $\begin{array}{l}\text { Pengaturan dalam } \\
\text { penanganan kesulitan } \\
\text { likuditas } \\
\text { Fatwa MUI dan fatwa } \\
\text { DSNMUI }\end{array}$ & $\begin{array}{l}\text { Peraturan Bank Indonesia Nomor } 5 / 3 / \mathrm{PBI} / 2003 \text { tentang } \\
\text { fasilitas pembiayaan jangka pendek bagi Bank syariah. } \\
\text { Mekanisme pemberian pembiayaan kepada bank syariah } \\
\text { dalam hal terjadinya kesulitan pendanaan jangka pendek } \\
\text { oleh Bank Indonesia sebagai the lender of last resort } \\
\text { - Fatwa tentang haramnya berbagai bunga (bunga bank, } \\
\text { asuransi, pegadaian) yang di keluarkan pada tanggal } 16 \\
\text { Desember } 2003 \text { dan di kukuhkan } 6 \text { Januari } 2001 \text {. Fatwa MUI } \\
\text { bahwa bunga bank adalah riba muncul dengan merujuk } \\
\text { pada ayat - ayat Alqur'an, khususnya Q.S An Nissa: 19; } \\
\text { Q.S An Nissa: 160-169; Q.S Ar rum:39; Q.S Ali Imran: 130; } \\
\text { dan Q.S Al Baqarah: 278 - 279; } \\
\text { - Fatwa DSN MUI tentang ekonomi syariah, lebih } \\
\text { mengukuhkan eksistensi perbankan syariah di tengah } \\
\text { pertumbuhan kegiatan usaha perbankan syariah. Hal } \\
\text { demikian merupakan kelanjutan dari fatwa tahun } 2000 \\
\text { Dewan Syariah Nasional, yaitu bahwa penerapan suku } \\
\text { bunga bank bertentangan dengan syariah islam. } \\
\text { - Peraturan Bank Indonesia Nomor 6/17/PBI/2004 tentang } \\
\text { Bank Prekreditan Rakyat Berdasarkan Prinsip Syariah dan } \\
\text { Peraturan Bank Indonesia Nomor 6/24/PBI/2004 tentang } \\
\text { Bank Umum yang Melaksanakan Kegiatan Usaha } \\
\text { Berdasarkan Prinsip Syariah: Pengawasan Syariah dan } \\
\text { Tata Cara Pelaporan Hasil Pengawasan bagi Dewan } \\
\text { Pengawasan Syariah } \\
\text { - Arsitektur Perbankan Indonesia }\end{array}$ \\
\hline 2005 & Peraturan permodalan & $\begin{array}{l}\text { Peraturan Bank Indonesia Nomor } 7 / 13 / \mathrm{PBI} / 2005 \text { tentang } \\
\text { Kewajiban Penyediaan Modal Minimum Bank Umum } \\
\text { Berdasarkan Prinsip Syariah: penyesuaian struktur } \\
\text { permodalan yang sejalan }\end{array}$ \\
\hline 2006 & $\begin{array}{l}\text { Penyesuian aturan } \\
\text { permodalan perbankan } \\
\text { syariahPenerapan office } \\
\text { channeling }\end{array}$ & $\begin{array}{l}\text { Peraturan Bank Nomor 8/7/PBI/2006 tentang Perubahan } \\
\text { atas Peraturan bank Indonesia Nomor } 7 / 13 / \text { PBI/2005 } \\
\text { tentang Kewajiban Penyediaan Modal Minimum Bank Umum } \\
\text { Berdasarkan Prinsip Syariah: penyesuaian ketentuan } \\
\text { mengenai kewajiban penyediaan modal minimum bank } \\
\text { umum berdasarkan prinsip syariah. Peraturan Bank } \\
\text { Indonesia Nomor } 8 / 3 / \text { PBI/2006, mengatur mengenai materi } \\
\text { penerapan office channeling bagi bank - bank syariah. } \\
\text { Kebijakan ini merupakan inovasi dan terobosan baru, }\end{array}$ \\
\hline
\end{tabular}




\begin{tabular}{|l|l|l|}
\hline TAHUN & PERISTIWA & \multicolumn{1}{c|}{ SUBSTANSI MATERI } \\
\hline & & $\begin{array}{l}\text { maksudnya kantor bank konvensional dapat melayani } \\
\text { transaksi - transaksi syariah, dengan syariah bank } \\
\text { bersangkutan telah memiliki unit usaha syariah (UUS). }\end{array}$ \\
& & $\begin{array}{l}\text { Dengan demikian, masyarakat dapat menabung } \\
\text { mendepositokan uangnya secara syariah di bank } \\
\text { knnensional yang memiliki unit usaha syariah tersebut } \\
\text { sehingga tidak harus ke kantor cabang bank syariah. }\end{array}$ \\
\hline
\end{tabular}

Lintasan peristiwa regulasi perbankan syariah di atas, hanya merupakan peristiwa yang cukup penting dan yang pokoknya saja, masih banyak peristiwa pengaturan perbankan syariah yang telah menjadi bagian dari sejarah perkembangan perbankan syariah di Indonesia.

Perbankan syariah pun muncul dengan menawarkan sistem bagi hasil, yakni nisbah keuntungan berupa porsi bagian untuk nasabah transaksi bank syariah harus bermanfaat sehingga menimbulkan nilai tambah dari setiap pembiayaan. Uang tetaplah sebagai alat tukar, karena itu tidak boleh dijadikan komoditas. Setiap transaksi harus spesifik dan transparan, oleh karena itu hal yang bersifat meragukan (gharar) harus dihindari. Demikianlah pula dengan risiko transaksi. Risiko transaksi mesti di kelola secara baik karena bank syariah merupakan pemegang amanah (mudharib).

Dalam salah satu tulisan yang di muat dalam BEI NEWS Edisi 18 Tahun V Januari - Februari 2004, mengenai "Apa Itu bank Syariah", dijelaskan terdapat sejumlah perbedaan karakteristik antara bank syariah dan bank konvensional, yaitu: a. bank syariah tidak melaksanakan transaksi pinjam - meminjam uang berdasarkan bunga dalam bentuk apa pun, tetapi dengan sistem bagi hasil dengan nasabahnya; b. hubungan antara bank syariah dan nasabah tidak berupa hubungan debitur kreditor, tetapi lebih pada hubungan partisipasi dalam menanggung risiko dan menerima hasil dari suatu perjanjian usaha; c. bank syariah memisahkan kedua jenis pendanaan supaya dapat dibedakan antara hasil yang di peroleh dari dana sendiri dan hasil yang diperoleh dari dana simpanan yang di terima atas dasar prinsip bagi hasil; d. bank syariah tidak memberikan pinjaman dalam bentuk uang tunai, tetapi bekerja sama atas dasar kemitraan, seperti mudharabaah, musyawarakah atas dasar jual beli (murabahah), atau atas dasar sewa (ijarah). Lima, dalam hal laba, bagi bank syariah bukan satu-satunya tujuan karena bank syariah mengupayakan bagaimana memanfaatkan sumber dana yang ada guna membangun kesejakteraan masyarakat. 
Dari segi manajemen antara bank konvensional dan bank berdasarkan prinsip syariah juga terdapat beberapa perbedaan. Hal itu dijelaskan oleh Chairuddin Syah Nasution, yaitu sebagai berikut: ${ }^{11}$

"Satu hal yang sangat menarik, yang membedakan antara manajemen bank muamalat dengan bank umum (konvensional) adalah terletak pada pembiayaan dan pemberian balas jasa, baik yang di terima oleh bank maupun investor. Jika dilihat pada bank umum, pembiayaan disebut loan, sementara di bank syariah di sebut financing. Sedangkan balas jasa yang diberikan atau di terima pada bank umum berupa bunga (interest loan atau deposit) dalam prosentase pasti. Sementara pada bank muamalat dengan sistem syariah, hanya memberi dan menerima balas jasa berdasarkan perjanjian (akad) bagi hasil. Selanjutnya, dalam perbankan syariah dikenal istilah mudharabah dan murabahah dan musyarakah untuk program pembiayaan. Bank syariah akan memperoleh keuntungan berupa bagi hasil, dari proyek yang di biayai oleh bank tersebut. Apabila proyeknya mandek, maka akan di carikan solusi penyelesaian. Misalnya, dengan menjual aset proyek. Uang penjualan aset proyek di biayai bank syariah, akan di bagi kepada bank dan nasabah sesuai penyertaan masing-masing pada usaha tersebut."

Saat ini di Indonesia, kondisi perbankan konvensional dengan perbankan syariah selain memiliki perbedaan karakteristik, serta perbedaan manajemen sebagaimana diuraikan di atas, juga masih menyisakan permasalahan adanya kondisi yang bertolak belakang antara peraturan yang ada dengan operasional kegiatan usaha perbankan syariah. Jenis kegiatan usaha yang diatur dalam UndangUndang Nomor 7 Tahun 1992 tentang Perbankan dan Perubahannya UndangUndang Nomor 10 Tahun 1998 tentang perubahan atas Undang-Undang Nomor 7 Tahun 1992 tentang Perbankan, sebagaimana telah dibahas di atas, bagi perbankan syariah menjadikannya suatu kendala karena banyak jenis jasa bank syariah yang tidak dapat ditawarkan karena banyak terhambat oleh ketentuan tersebut.

Sutan Remy Sjahdeni menyebutkan adanya batasan praktik perbankan dalam Pasal 6 dan 7 Undang-Undang Nomor 7 Tahun 1992 tentang Perbankan yang melarang bank melakukan penyertaan modal, kecuali pada bank atau perusahaan lain di bidang keuangan. Hal ini tentu bertolak belakang dengan praktik bank syariah. Salah satu jenis usaha bank syariah adalah melakukan transaksi penjualan, antara lain, dalam bentuk yang disebut murabahah. Ini akan jadi bertolak belakang kalau bank syariah dilarang melakukan usaha yang menjadi fokus usahanya. Selanjutnya, menghadapi permasalahan tersebut, Remy menuntut dibentuknya

${ }^{11}$ Chairuddin Syah Nasution dalam tulisannya yang berjudul “Manajemen Kredit Syariah Bank Muamalat", yang di muat dalam Kajian Ekonomi dan Kenangan, Volume 7, Nomor 3, September 2003. 
undang-undang tersendiri bagi bank syariah di luar ketentuan perbankan yang telah ada. Selain adanya masalah praktik, sistem akuntansi antara bank syariah juga perbedaan dengan bank konvensional. Sehingga laporan keuangan, yakni neraca laba/rugi dari bank syariah akan berbeda dengan yang konvensional. ${ }^{12}$

Sasaran pengembangan bank syari'ah hingga 2011: a. terpenuhinya prinsip syari'ah dalam operasional perbankan yang ditandai dengan: 1) tersusunnya normanorma keuangan syari'ah yang seragam (standardisasi). 2) terwujudnya mekanisme kerja yang efisien bagi pengawasan prinsip syari'ah dalam operasional perbankan (baik instrumen maupun badan terkait). 3) rendahnya tingkat keluhan masyarakat dalam hal penerapan prinsip syariah dalam setiap transaksi. b. diterapkannya prinsip kehati-hatian dalam operasional perbankan syariah: 1) terwujudnya kerangka pengaturan dan pengawasan berbasis risiko yang sesuai dengan karakterstiknya dan di dukung oleh sumber daya manusia yang andal. 2) diterapkannya konsep good corporate governance dalam operasi perbankan syari'ah. 3) diterapkannya kebijakan exit dan entre yang efisien. 4) terwujudnya realtime supervision. 5) terwujudnya self regulatory system. c. terciptanya sistem perbankan syari'ah yang kompetitif dan efisien,yang ditandai dengan: 1) terciptanya pemain-pemain yang mampu bersaing secara global; 2) terwujudnya aliansi strategis yang efektif; 3) terwujudnya mekanisme kerja sama dengan lembaga-lembaga pendukung. d. terwujudnya stabilitas sistemik serta terealisasinya kemanfaatan bagi masyarakat luas, yang di tandai dengan : 1) terwujudnya safety net yang menyatu dengan konsep operasional perbankan yang berhati-hati; 2) terpenuhinya kebutuhan masyarakat yang menginginkan layanan bank syari'ah diseluruh Indonesia dengan target pangsa sebesar 5\% dari total aset perbankan nasional. 3) terwujudnya fungsi perbankan syari'ah yang kaffah dan dapat melayani seluruh segmen masyarakat. 4) meningkatnya proporsi pola pembiayaan secara bagi hasil.

Secara ringkas, sasaran pengembangan perbankan syariah adalah: meningkatkan manfaat perbankan syariah bagi kesejahteraan masyarakat; mewujudkan perbankan syariah yang sehat, kompetitif, dan efisien; menjamin pemenuhan prinsip syariah secara konsisten berdasarkan mudharabah (partner ship); dan menjamin prinsip kehatihatian.

Bank Indonesia telah banyak mendorong pengembangan perbankan syariah nasional, meskipun begitu masih ada celah-celah yang belum sepenuhnya mendapat

${ }^{12}$ http:/ / cms.sip.co.id/hukumonline/detail.asp?id=9235\&cl=Berita 
dukungan pemerintah seyogianya mendukung pengembangan investasi syariah, di antaranya dapat berupa pemberian perlakuan perpajakan yang khusus. Selama ini di Indonesia belum ada peraturan yang secara spesifik mengatur pengenaan pajak atas produk bank syariah, seperti produk jual beli (murabahah, isthisna, dan salam) serta bagi hasil (mudharabah, musyarakah, dan ijarah).

Lihat bagaimana pemerintah Malaysia yang memiliki kebijakan akomodatif terhadap pengembangan instrumen dan lembaga keuangan syariah dengan menyempurnakan Undang-Undang Perpajakan untuk mengakomodasi kebutuhan Bank Syariah pada 1995, atau juga bisa meniru yang terjadi di Pakistan melalui Pakistani Income Tax Ordinance 1979 yang mengatur khusus tentang pajak penghasilan dalam produk mudharabah dan ijarah. Bahkan, Indonesia mungkin perlu mengaca pada otoritas Inggris lewat Stamp Duty Land Tax (efektif 1 Desember 2003) dan Australia (The State Taxation Act 2004, di Victoria) yang sejak dua tahun terakhir memberikan fasilitas pengecualian perlakuan perpajakan transaksi keuangan syariah. ${ }^{13}$

\section{Produk Bank Syariah}

Adapun Produk - produk bank Syariah adalah sebagai berikut: ${ }^{14}$

\section{Al-wadi'ah (simpanan)}

Al-wadi'ah merupakan titipan atau simpanan pada bank syariah. Prinsip Alwadi'ah merupakan titipan murni dari satu pihak ke pihak lain, baik perorangan maupun badan hukum yang harus dijaga dan dikembalikan kapan saja bila penitip menghendaki. Penerima simpanan disebut yad-amanah yang artinya tangan amanah. Penyimpan tidak bertanggung jawab atas segala kehilangan dan kerusakan yang terjadi pada titipan selama hal itu bukan akibat dari kelalaian dan kecerobohan yang bersangkutan dalam memelihara barang titipan.

Akan tetapi dewasa ini agar uang yang dititipkan tidak menganggur begitu saja, oleh penyimpan uang titipan tersebut (bank syariah) digunakan untuk kegiatan perekonomian. Tentu saja penggunaan uang titipan harus terlebih dahulu meminta izin kepada pemilik uang dan dengan catatan pengguna uang menjamin akan mengembalikan yang tersebut secara utuh. Dengan demikian prinsip yad al-amanah

${ }^{13}$ Fahmi Achmad \& M. Haikal,’Indonesia Siap Menjadi Hub Dana Syariah Internasional”, http:// www.bisnis.com/servlet/page? pageid $=127 \& \mathrm{dad}=$ portal30\& schema=PORTAL30\&vnw lang id=2\&ptopik= A15\&cdate $=14$ APR-2005\&inw id $=356389$

${ }^{14}$ Ibid., hlm. 179 
(tangan amanah) menjadi yad adh-dhamanah (tangan penanggung). Mengacu pada prinsip yad adh-dhamanah bank sebagai penerima dana dapat memanfaatkan dana titipan seperti simpanan giro dan tabungan, dan deposito berjangka untuk dimanfaatkan bagi kepentingan masyarakat dan kepentingan negara. Yang terpenting dalam hal ini penyimpan bertanggung jawab atas segala kehilangan dan kerusakan yang menimpa uang tersebut.

Konsekuensi dari diterapkannya prinsip yad adh-dhamanah pihak bank akan menerima seluruh keuntungan dari penggunaan uang, namun sebaliknya, jika mengalami kerugian juga harus ditanggung oleh bank. Sebagai imbalan kepada pemilik dana di samping jaminan keamanan uangnya juga akan memperoleh fasilitas lainnya seperti insentif atau bonus untuk giro wadiah. Artinya bank tidak dilarang untuk memberikan jasa atas pemakaian uangnya berupa insentif atau bonus biasanya digunakan istilah nisbah atau bagi hasil antara bank dengan nasabah. Bonus biasanya diberikan kepada nasabah yang memiliki dana rata-rata minimal yang telah ditetapkan.

Praktik nisbah antara bank (shabibul maal) dengan deposan (mudharib) berupa bonus untuk giro waiah sebesar 30\%, nisbah 40 : 60 untuk simpanan tabungan dan nisbah 45 : 55 untuk simpanan deposito. Untuk memudahkan perhitungan nisbah ketiga simpanan di atas berikut ini akan diberikan beberapa contoh yang mudah dipahami berikut ini.

\section{Pembiayaan dengan Bagi Hasil}

Penyaluran dana dalam Bank Konvensional, kenal dengan istilah kredit atau pinjaman. Sedangkan dalam Bank Syariah untuk penyaluran dananya kenal dengan istilah pembiayaan. Jika dalam Bank Konvesional keuntungan bank diperoleh dari bunga yang dibebankan, maka dalam Bank Syariah tidak ada istilah bunga, akan tetapi Bank Syariah menerapkan sistem bagi hasil.

Prinsip bagi hasil dalam Bank Syariah yang diterapkan dalam pembiayaan dapat dilakukan dalam 4 akad utama, yaitu: a. al-musyarakah, al-musyarakah merupakan akad kerjasama antara dua pihak atau lebih untuk melakukan usaha tertentu. Masing-masing pihak memberikan dana atau amal dengan kesepakatan bahwa keuntungan atau resiko akan ditanggung bersama sesuai dengan kesepakatan. Dalam praktik perbankan Al-musyarakah diaplikasikan dalam hal pembiayaan proyek. Nasabah yang dibiayai dengan bank sama-sama menyediakan dana untuk melaksanakan proyek tersebut. Keuntungan dari proyek dibagi sesuai dengan kesepakatan untuk bank setelah terlebih dahulu mengembalikan dana yang 
dipakai nasabah. Al-musyarakah pada lembaga keuangan modal ventura. b. almudharabahm, al-mudharabah merupakan akad kerja sama antara dua pihak di mana pihak pertama menyediakan seluruh modal dan pihak lain menjadi pengelola. Keuntungan dibagi menurut kesepakatan yang dituangkan dalam kontrak. Apabila rugi, maka akan ditanggung pemilik modal selama kerugian itu bukan akibat dari kelalaian pengelola. Apabila kerugian diakibatkan kelalaian pengelola, maka pengelolah yang bertanggung jawab.

Praktik mudharabah dibagi dalam 2 jenis, yaitu mudharabah muthlaqah dan mudharabah muqayyab. Pengertian mudharabah muthlaqah merupakan kerjasama antara pihak pertama dan pihak lain yang cakupannya lebih luas. Maksudnya tidak dibatasi oleh waktu, spesifikasi usaha dan daerah bisnis. Sedangkan mudharabah muqayyah merupakan kebalikan dari mudharabah muthlaqah dimana pihak lain dibatasi oleh waktu spesifikasi usaha dan daerah bisnis.

Dalam dunia perbankan Al-mudharabah biasanya diaplikasikan pada produk pembiayaan atau pendanaan seperti, pembiayaan modal kerja. Dana untuk kegiatan mudharabah diambil dari simpanan tabungan berjangka seperti tabungan haji atau tabungan kurban. Dana juga dapat dilakukan dari deposito biasa dan deposito spesial yang dititipkan nasabah untuk usaha tertentu.

\section{Al-muza'arah}

Al-muza'arah merupakan kerja sama pengolahan pertanian antara pemilik lahan dengan penggarap. Pemilik lahan menyediakan lahan kepada penggarap untuk ditanami produk pertanian dengan imbalan bagian tertentu dari hasil panen. Dalam dunia perbankan kasus ini diaplikasikan untuk pembiayaan bidang plantation atas dasar bagi hasil panen.

Pemilik lahan dalam hal ini menyediakan lahan, benih dan pupuk. Sedangkan penggarap menyediakan keahlian, tenaga dan waktu. Keuntungan diperoleh dari hasil panen dengan imbalan yang telah disepakati.

\section{Al-musaqah}

Pengertian Al-musaqah adalah bagian dari Al-muza'arah yaitu penggarap hanya bertanggung jawab atas penyiraman dan pemeliharaan dengan menggunakan dana dan peralatan mereka sendiri. Imbalan tetapi diperoleh dari persentase hasil panen pertanian. Jadi, tetap dalam konteks adalah kerja sama pengolahan pertanian antara pemilik lahan dengan penggarap. 


\section{Bai'al-Murabahah}

Bai'al-Murabahah merupakan kegiatan jual beli pada harga pokok dengan tambahan keuntungan yang disepakati. Dalam hal ini penjual harus terlebih dulu memberitahukan harga pokok yang ia beli ditambah keuntungan yang diinginkannya.

\section{Bai'as-salam}

Bai'as-salam adalah pembelian barang yang diserahkan kemudian hari, sedangkan pembayaran dilakukan dimuka. Prinsip yang harus dianut terlebih dulu jenis, kualitas dan jumlah barang dan hukum awal pembayaran harus dalam bentuk uang.

\section{Bai'Al-istihna}

Bai'Al-istihna adalah bentuk khusus dari akad Bai'as-salam, oleh karena itu ketentuan dalam Bai'Al-istihna mengikuti ketentuan dan aturan Bai'as-salam. Pengertian Bai' Al-istihna adalah kontrak penjualan antara pembeli dengan produsen (pembuat barang). Kedua belah pihak harus saling menyetujui atau sepakat lebih dulu tentang harga dan sistem pembayaran. Kesepakatan harga dapat dilakukan tawar-menawar dan sistem pembayaran dapat dilakukan di muka atau secara angsuran perbulan atau dibelakang.

\section{Al-Ijarah (Leasing)}

Al-Ijarah merupakan akad pemindahan hak guna atas barang atau jasa, melalui pembayaran upah sewa, tanpa diikuti dengan pemindahan kepemilikan atas barang itu sendiri. Dalam praktiknya kegiatan ini dilakukan oleh perusahaan leasing, baik untuk kegiatan operating lease maupun financial lease.

\section{Al-Wakalah (Amanat)}

Wakalah atau wakilah artinya penyerahan atau pendelegasian atau pemberian mandat dari satu pihak kepada pihak lain. Mandat ini harus dilakukan sesuai dengan yang telah disepakati oleh si pemberi mandat.

\section{Al-Kafalah (Garansi)}

Pengertian Al-Kafalah adalah jaminan yang diberikan penanggung kepada pihak ketiga untuk memenuhi kewajiban pihak kedua atau yang ditanggung. Dapat pula diartikan sebagai pengalihan tanggung jawab dari satu pihak kepada pihak lain. Dalam dunia perbankan dapat dilakukan dalam hal pembiayaan dengan jaminan seseorang. 


\section{Al-Hawalah}

Al-Hawalah merupakan pengalihan utang dari yang berutang kepada orang lain yang wajib menanggungnya. Atau dengan kata lain pemindahan beban utang dari satu pihak kepada pihak lain. Dalam dunia keuangan atau perbankan dikenal dengan kegiatan anjak piutang atau factoring.

\section{Ar-Rahn}

Ar-Rahn adalah kegiatan menahan salah satu harta milik si peminjam sebagai jaminan atas pinjaman yang diterimanya. Kegiatan seperti ini dilakukan seperti jaminan utang atau gadai.

\section{Penutup}

Kehadiran bank yang berdasarkan syari'ah di Indonesia masih relatif baru, yaitu baru pada awal 1990-an, meskipun masyarakat Indonesia merupakan masyarakat muslim terbesar di dunia. Prakarsa untuk mendirikan Bank Syari'ah di Indonesia dilakukan oleh Majelis Ulama Indonesia (MUI) pada 18-20 Agustus 1990. Namun diskusi tentang bank syariah sebagai basis ekonomi Islam sudah mulai dilakukan pada awal 1980. Kehadiran Bank Islam membawa pengaruh pada perkembangan bank-bank, sehingga sudah tersebar di berbagai negara-negara muslim dan non muslim, yaitu: di Benua Amerika, Australia dan Eropa. Bahkan banyak perusahaan keuangan dunia seperti ANZ, Chase Chemical Bank dan Citibank telah membuka cabang yang berdasarkan syariah. Perbankan syariah memiliki dinamika, mekanisme, dan perkembangan sendiri. Di Indonesia, kajian tentang perbankan syariah sudah muncul sejak 1980-an. Namun, realisasinya baru pada 1991 dengan munculnya bank syariah pertama di Indonesia, yaitu Bank Muamalat Indonesia (BMI) yang mulai beroperasi pada 1992.

Perbankan syariah pun muncul dengan menawarkan sistem bagi hasil, yakni nisbah keuntungan berupa porsi bagian untuk nasabah transaksi bank syariah harus bermanfaat sehingga menimbulkan nilai tambah dari setiap pembiayaan. Setiap transaksi harus spesifik dan transparan, oleh karena itu hal yang bersifat meragukan (gharar) harus di hindari. Demikian pula dengan risiko transaksi. Risiko transaksi mesti di kelola secara baik karena bank syariah merupakan pemegang amanah (mudharib). Memperhatikan kondisi dan karakteristik yang khusus dari suatu sistem perbankan syariah sebagaimana telah di uraikan di atas di perlukan penanganan 
dan penyelesaiannya. Suatu yang tidak berlebihan jika bank Indonesia menyikapinya dalam kapasitasnya sebagai pengawas perbankan, kemudian menentukan dan menetapkan sasaran realistis untuk mewujudkan visi perbankan syari'ah yang kompetitif, efisien, dan memenuhi prinsip ke hati-hatian. Produk-produk yang ditawarkan sudah tentu sangat islami, termasuk dalam memberikan pelayanan kepada nasabahnya.

Adapun jenis-jenis produk bank Syariah yang ditawarkan adalah: Al-wadi'ah (simpanan), Pembiayaan dengan bagi hasil, Bai'al-Murabahah, Bai'as-salam, Bai' Al-istihna, AlIjarah (Leasing), Al-Wakalah (Amanat), Al-Kafalah (Garansi), Al-Hawalah, Ar-Rahn. Secara ringkasnya, sasaran pengembangan perbankan syariah adalah: meningkatkan manfaat perbankan syariah bagi kesejahteraan masyarakat; mewujudkan perbankan syariah yang sehat, kompetitif, dan efisien; menjamin pemenuhan prinsip syariah secara konsisten berdasarkan mudharabah (partner ship); dan menjamin prinsip kehati-hatian.

Diharapkan pemerintah melakukan penyempurnaan ketentuan perpajakan yang mengakomodasi transaksi dan kegiatan usaha lembaga keuangan syariah yang pada prinsipnya tidak hanya memberikan kepastian tentang kesetaraan penerapan pungutan pajak yang memberikan keuntungan kepada negara, tetapi juga merupakan prasyarat bagi terciptanya industri yang efisien yang stabil secara sistem.

\section{Daftar Pustaka}

Abdurrahman, A., Ensikopedia Ekonomi Keuangan Perdagangan, Pradnya Paramita, Jakarta, 1993.

Achmad, Fahmi, \& M. Haikal,"Indonesia Siap Menjadi Hub Dana Syariah Internasional", http://www.bisnis.com/servlet/page pageid=127\& dad=portal30\& schema=PORTAL30\&vnw lang id=2\&ptopik=A15\&cdate= 14APR-2005\&inw id=356389.

Edy Putra, Mgs., Kredit Perbankan Suatu Tinjauan Yuridis, Liberty, Yogyakarta, 1989.

Gandapradja, Permadi, Dasar dan Prinsip Pengawasan Bank, PT Gramedia Pustaka Utama, Jakarta, 2005.

Mahmud Marzuki, Peter, Penelitian Hukum, Preneda Media, Jakarta, 2005.

Muhamad, Djumhana, Hukum Perbankan di Indonesia, PT Citra Aditya Bakti, Bandune, 1996.

P. Soerjadi, Sidharta, Segi-segi Hukum Perkreditan di Indonesia, Kertas Kerja dalam Simposium Aspek-aspek Hukum Masalah Perkreditan, BPHN Binacipta, 1987. 
Savelberg, Hala , De crediet hypotheek, Leiden, 1885.

Sembiring, Sentosa, Hukum Perbankan, Mandar Maju, Bandung, 2000.

Soekanto, Soerjono dan Sri Mamudji, Penelitian Hukum Normatif: Suatu Tinjauan Singkat, Jakarta, 1990.

Syarif Surbakti, Muhammad, Pengaturan Khusus Bagi Perbankan Syariah, http:/ / www.tazkiaonline.com/artikel,php3?sid=517.

Syah Nasution, Chairuddin, dalam tulisannya yang berjudul "Manajemen Kredit Syariah Bank Muamalat", yang di muat dalam Kajian Ekonomi dan Keuangan, Volume 7, Nomor 3, September 2003.

http:/ / cms.sip.co.id/hukumonline/detail.asp?id=9235\&cl=Berita 